\title{
An empirical research on the vocational ability based on the business sand table simulation training
}

\author{
Chunshang Wu \\ Heyuan Polytechnic, Heyuan City, Guangdong Province, 517000, China \\ wuchunshang1023@163.com
}

Keywords: Business sand table simulation training, Vocational ability, Empirical study.

\begin{abstract}
Business sand table simulation training innovates vocational ability cultivation mode in management through game-based experience learning. Through teaching practice, it is found that business management, accounting, marketing and logistics management professional skills can be effectively trained in business sand table simulation training. But win-win consciousness, integrity awareness and logistics expertise are failed to train effectively.
\end{abstract}

\section{Introduction}

Traditional classroom teaching can only allow students to learn the classic management theory, but it can not be used in practice, so it can not meet the needs of the enterprise. Therefore, the school introduced the case teaching method to strengthen students' management skills, but because the students are not familiar with the background of the case, they can't really invest. So there is still a great deviation in the mastery of management skills. Later, many schools wanted to solve the gap between theory and practice by sending students to internships. However, enterprises can only arrange front-line positions, which cannot train students' management skills at all.

The business sand table simulation training can effectively train students' management skills by allowing students to simulate and operate a company and play different roles. Teaching practice shows that the course can effectively improve students' professional ability and professional skills, and students have higher interest in learning.

\section{Training of students' professional ability and professional skills in the business sand table simulation training}

In the business sand table simulation training, students form their own team to simulate the operation of a manufacturing company, which plays the roles of CEO, production director, marketing director, purchasing supervisor, and financial director respectively, so that students can make real market competition and according to the enterprise environment. And also can take business decisions, gain corporate profits. Game-based experience teaching and role-playing allow students to acquire professional ability in the immersion.

Due to the use of the full simulation of the business process, it is conducive to students to establish a win-win concept, innovation awareness and overall awareness and teamwork spirit, communication skills, anti-frustration ability, analytical problems and problem-solving skills, etc.

Since the course objectives are determined based on the professional competence and requirements of the company's management jobs, he course allows the students to simulate the operation of a manufacturing company in the same competitive environment. The students can play the production manager, sales manager, financial manager, logistics manager, etc., therefore it can effectively improve the professional skills of the various majors in the management category. Of course, different major should focus on the different content.

In the course, business management students play the role of general manager, production manager, purchasing manager, because the production and operation of enterprises are the core and emphasis in the sand table course, and the professional skills can be fully trained. 
Accounting students play the role of financial manager, marketing professional students play the role of sales manager. Financial skill is not only related to whether an enterprise can make a profit, or even if the financial budget is not good or directly due to the bankruptcy of capital outflow. The course simulates the business and operating environment of real enterprises, so more accounting skills can be applied, and students' mastery of accounting skills can be reflected directly by simulating the business conditions of enterprises, which greatly stimulates students to learn financial knowledge and skills.

Marketing students act as marketing managers. Students need to develop different marketing strategies according to different market conditions. Students cooperate with each other to combine marketing, marketing planning, Market Research and forecasting theory with practice, and acquire marketing skills by participating in business. Students' interest in learning have been significantly improved.

Logistics students play the role of purchasing manager. In addition to general management skills, Students can also train purchasing management skills, product inventory management skills and supply chain management skills.

The skill points of each major are shown in table 1 .

Table 1 the skill points of each major

\begin{tabular}{|c|c|c|c|c|c|c|}
\hline \multirow{2}{*}{ Major } & \multicolumn{6}{|c|}{ Skill points } \\
\hline & 1 & 2 & |3 & 4 & 5 & 6 \\
\hline Logistics & $\begin{array}{l}\text { Purchasing } \\
\text { management }\end{array}$ & $\begin{array}{c}\text { Inventory } \\
\text { management }\end{array}$ & \begin{tabular}{|c|} 
Supply \\
Chain \\
Management
\end{tabular} & & & \\
\hline Marketing & $\begin{array}{c}\text { Market } \\
\text { prediction }\end{array}$ & Marketing & $\begin{array}{c}\text { Sales } \\
\text { management } \\
\end{array}$ & $\begin{array}{c}\text { Market } \\
\text { Development } \\
\end{array}$ & & \\
\hline $\begin{array}{l}\text { Business } \\
\text { management }\end{array}$ & $\begin{array}{c}\text { Corporate } \\
\text { strategic } \\
\text { management }\end{array}$ & $\begin{array}{c}\text { Demand } \\
\text { forecasting and } \\
\text { R\&D decisions }\end{array}$ & $\begin{array}{c}\text { Investment } \\
\text { decision }\end{array}$ & $\begin{array}{c}\text { Production } \\
\text { management }\end{array}$ & $\begin{array}{l}\text { Quality } \\
\text { Control }\end{array}$ & $\begin{array}{c}\text { Human } \\
\text { resources } \\
\text { management }\end{array}$ \\
\hline Accounting & Financial budget & $\begin{array}{c}\text { Financing } \\
\text { decision }\end{array}$ & \begin{tabular}{|c|} 
Fund \\
management
\end{tabular} & $\begin{array}{c}\text { Make financial } \\
\text { statements }\end{array}$ & \begin{tabular}{|c|}
$\begin{array}{c}\text { Accounting } \\
\text { bookkeeping }\end{array}$ \\
\end{tabular} & $\begin{array}{c}\text { Financial } \\
\text { analysis }\end{array}$ \\
\hline
\end{tabular}

As can be seen from Table 1, there are many skill points in accounting majors and business management majors, students' professional skills are fully trained. While logistics majors and marketing majors have a few skill points, so the professional skills training of them are not sufficient.

\section{Analysis on the effect of training professional skills in sandbox simulation in the business sand table simulation training}

In order to understand the teaching effectiveness and shortcomings of the course, a questionnaire survey was conducted on 563 students of Heyuan Polytechnic, Including business administration, marketing, accounting, logistics majors .The questionnaire is divided into two parts. The first part is the overall view of the course, and the second part is the effect of the course on professional ability training.

563 questionnaires were distributed and 560 questionnaires were collected. The recovery rate was $99.5 \%$, while 536 questionnaires were valid questionnaires. The results are shown in Table 2, Table 3, and Table 2. 
Table 2 Students' overall evaluation of the course ( \%)

\begin{tabular}{|c|c|c|c|c|c|}
\hline Investigation question & $\begin{array}{c}\text { Very } \\
\text { satisfied }\end{array}$ & Satisfied & General & $\begin{array}{c}\text { Not } \\
\text { satisfied }\end{array}$ & $\begin{array}{c}\text { Very } \\
\text { dissatisfied }\end{array}$ \\
\hline $\begin{array}{c}\text { Are you satisfied with the content of the } \\
\text { course? }\end{array}$ & 42 & 50 & 8 & 0 & 0 \\
\hline Are you satisfied with the teaching method? & 53 & 40 & 7 & 0 & 0 \\
\hline Are you satisfied with the teaching effect? & 58 & 36 & 6 & 0 & 0 \\
\hline
\end{tabular}

It can be seen from Table 3 that the students are very satisfied with the overall teaching effect of the course. The satisfaction of teaching content, teaching methods and teaching effects are all above 90\%, respectively 92\%, 94\%, 92\%.

Table 3 Evaluation of students' general vocational ability in curriculum development (\%)

\begin{tabular}{c|c|c|c|c|c}
\hline $\begin{array}{c}\text { General vocational } \\
\text { ability }\end{array}$ & $\begin{array}{c}\text { Significantly } \\
\text { improved }\end{array}$ & $\begin{array}{c}\text { Greatly } \\
\text { improved }\end{array}$ & General & Not obvious & $\begin{array}{c}\text { No } \\
\text { improvement }\end{array}$ \\
\hline Win-win awareness & 10 & 16 & 23 & 32 & 19 \\
\hline Communication skills & 36 & 45 & 12 & 7 & 0 \\
\hline Teamwork & 53 & 42 & 5 & 0 & 0 \\
\hline $\begin{array}{c}\text { Analyze and solve } \\
\text { problems }\end{array}$ & 48 & 47 & 5 & 0 & 0 \\
\hline Anti-frustration ability & 46 & 44 & 7 & 3 & 0 \\
\hline Integrity & 11 & 21 & 27 & 28 & 13 \\
\hline Innovative mind & 26 & 29 & 31 & 9 & 5 \\
\hline
\end{tabular}

From Table 3, it can be seen that general management ability has been greatly improved through the course, especially the communication ability, teamwork, Analyze and solve problems, and anti-frustration ability have been greatly improved, the ratio is $81 \%, 95 \%, 95 \%, 90 \%$. However the effect of innovation consciousness is not obvious, the number of people who think that there is a significant improvement is only $26 \%$.The effect of students' win-win awareness and Integrity is also not obvious, the effect obove generally is only $49 \%$ and $59 \%$.

Table 4 Evaluation of the training effect of curriculum professional skills

\begin{tabular}{|c|c|c|c|c|c|}
\hline Major & $\begin{array}{c}\text { Significantly } \\
\text { improved }\end{array}$ & $\begin{array}{c}\text { Greatly } \\
\text { improved }\end{array}$ & General & Not obvious & $\begin{array}{c}\text { No } \\
\text { improvement }\end{array}$ \\
\hline $\begin{array}{c}\text { Business } \\
\text { management }\end{array}$ & 37 & 56 & 5 & 2 & 0 \\
\hline Accounting & 40 & 53 & 4 & 3 & 0 \\
\hline Marketing & 32 & 53 & 11 & 4 & 0 \\
\hline Logistics & 28 & 42 & 18 & 8 & 4 \\
\hline
\end{tabular}

It can be seen from Table 4 that in the effect of training professional special skills of business management and accounting is obvious, the ratios above greatly improved are more than $90 \% 90 \%$. However, the effect of logistics is worse, and the ratio above greatly improved is only $70 \%$. The effect of marketing is in the middle, the ratio above greatly improved is $85 \%$.

\section{Suggestions on Improving the Training Effect of Curriculum Professional Skills}

The business sand table simulation training has innovated the teaching methods of the practical courses of economics and management, which has enhanced the enthusiasm of students to participate in the classroom and to participate in the curriculum learning. It also has significant help for the study 
of students' knowledge and skills.

However, judging from the survey results, there are still problems in the training of students' win-win awareness, integrity, and logistics professional skills. This has both the reasons for teachers' organization of teaching and the reasons for the design of the curriculum. In order to achieve better teaching results, the following aspects are worth noting.

First of all, optimize the assessment methods of the curriculum, establish a assessment method based on formative assessment, and dilute the assessment of business results. In the course assessment, some teachers take the business performance as the most important weight indicator of the assessment, even as the only assessment indicators, which directly lead to students to prevent vicious competition, mutual suppression, and even cheat to obtain good business performance. This is also the main reason for the poor performance of the business operation in the previous questionnaire. Therefore, more attention should be paid to the assessment of the student's simulated business process, and weaken business performance assessment.

Second, establish a high-level teaching team. As the course spans management, finance and economics, teachers are required to understand not only finance and accounting, but also management, sales and logistics. Therefore, it is necessary to complement the shortcomings of teachers by means of selection, training, and going out to study. So that, teachers are proficient in all the knowledge and skills involved, as to ensure that students can be guided in depth and easily. Otherwise, when students ask about financial knowledge or production knowledge, teachers can not give a reply, the teaching effect will be greatly reduced.

Finally, teachers should jump out of sand table to teach sand table courses. For the sake of students to understand easily, the course simplifies abstractly the management of real enterprises, and some rules even simplify too much, which is different from the actual management of enterprises. This requires teachers to jump out of the sand table when explaining, and tell students how the enterprise actually operates, in order to make the courses really become the ground gas, simulation and practice of the combination of comprehensive practical courses.

\section{Acknowledgements}

This work was financially supported by the project of Educational Science Planning in Guangdong” Research and Exploration on the practice teaching mode of economics and management-Improving students' comprehensive ability based on multi-level virtual simulation training”(2017GGXJK064)

\section{References}

[1] Jianxiong You. A brief analysis of the application of ERP sand table simulation practice teaching in the economic and management specialty training course of Higher Vocational colleges [J]. Economic Research Guide, 2013 (23): 172-173.

[2] Xuesong Hu. ERP sand table simulation teaching mode in Colleges and universities [J]. China business circle, 2010 (9): 277-277.

[3] Caixia Xue. Shunbo Yao. ERP sand table simulation teaching on business management students ability training effect analysis [J].Higher Education Forum, 2013 (10): 44-47.

[4] Yaming Sun. Zhang fan. Some thoughts on ERP sand table simulation course for economics and management specialty in local universities[J].Journal of Lanzhou Institute of Education, 2014 (6): 93-94.

[5] Qin Long. ERP sand table simulation embedded in marketing practice teaching[J].Trade Union Forum (Journal of Shandong Institute of Trade Union Management Cadres), 2011 (5): 126-127. 